\title{
Absence of Glutathione S-Transferase Theta 1 Gene is Significantly Associated with Breast Cancer Susceptibility in Pakistani Population and Poor Overall Survival in Breast Cancer Patients: A Case-Control and Case Series Analysis
}

\author{
Sadia Ajaz ${ }^{1 *}$, Sani-e-Zehra Zaidi ${ }^{1}$, Saleema Mehboob Ali ${ }^{1}$, Aisha Siddiqa ${ }^{2}$, Muhammad Ali \\ Memon $^{2}$, Sadaf Firasat ${ }^{3}$, Aiysha Abid ${ }^{3}$, Shagufta Khaliq ${ }^{4}$
}

1. Dr. Panjwani Center for Molecular Medicine and Drug Research (PCMD), International Center for Chemical and Biological Sciences (ICCBS), University of Karachi, Karachi-75270, Pakistan.

2. Atomic Energy Medical Centre (AEMC), Jinnah Postgraduate Medical Centre (JPMC), Karachi, Pakistan.

3. Centre for Human Genetics and Molecular Medicine, Sindh Institute of Urology and Transplantation (SIUT), Karachi, Pakistan.

4. Department of Human Genetics and Molecular Biology, University of Health Sciences, Lahore, Pakistan.

\section{"Corresponding Author:}

Sadia Ajaz, Ph. D.

E-mail: sadiaajaz.pcmd@iccs.edu 


\begin{abstract}

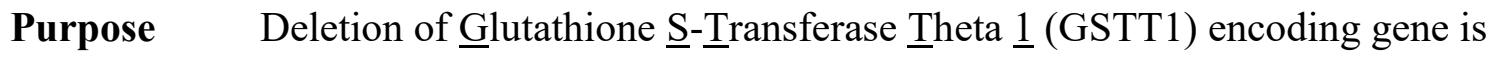
implicated in breast cancer susceptibility, clinical outcomes, and survival. Contradictory results have been reported in different studies. The present investigation evaluated GSTT1-absent genotype for its' contribution to breast cancer risk in Pakistani population and specific clinical outcomes in breast tumours.
\end{abstract}

Methods A prospective study comprising case-control analysis and case series analysis components was designed. Peripheral blood samples were collected from enrolled participants. After DNA extraction, GSTT1 genotyping was carried out by a multiplex PCR with $\beta$-globin as an amplification control. Association evaluation of GSTT1 genotypes with breast cancer risk, specific tumour characteristics, and survival was the primary endpoint.

Results A total of 264 participants were enrolled in the molecular investigation (3 institutions). The study included 121 primary breast cancer patients as cases and 143 agematched female subject, with no history of any cancer, as controls. A significant genetic association between GSTT1-absent genotype and breast cancer susceptibility ( $p$-value: 0.003; OR: 2.13 ; 95\% CI: $1.08-4.29$ ) is reported. The case-series analysis showed lack of association of GSTT1 genotypes with tumour stage ( $p$-value: 0.12 ), grade ( $p$-value: 0.32$)$, and size ( $p$-value: 0.07). The survival analysis revealed that GSTT1-absent genotype cases had a statistically significant shorter overall survival (OS) than those with GSTT1-present genotype cases (mean OS: 23 months vs 33 months). The HR (95\% CI) for OS in patients carrying GSTT1-absent genotype was 8.13 (2.91-22.96) when compared with GSTT1-present genotype.

Conclusions The present study is the first report of an independent, population-oriented significant genetic association between GSTT1-absent genotype and breast cancer susceptibility 
medRxiv preprint doi: https://doi.org/10.1101/2021.02.18.21252044; this version posted February 23, 2021. The copyright holder for this preprint (which was not certified by peer review) is the author/funder, who has granted medRxiv a license to display the preprint in perpetuity. All rights reserved. No reuse allowed without permission.

as well as OS in breast cancer cases. Upon further validation, GSTT1 variation may serve as a marker for devising better and population-specific strategies for screening and treatment in breast cancer management.

\section{Keywords:}

Breast cancer; Molecular epidemiology; Polymorphism; Null genotype; GSTT1-absent; GSTT1present 


\section{Introduction}

Glutathione is present in all living cells. Physiologically, it performs three important functions: protection of thiol groups in proteins from oxidation, intracellular redox buffering, storage for

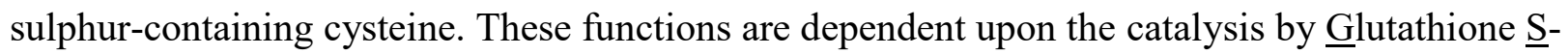
Transferases, E.C. 2.5.1.18. Consequently, GSTs play a major role in detoxification of potent endogenous and exogenous carcinogens [1]. These enzymes constitute a superfamily of isoenzymes including GST- theta $\underline{1}$. GSTT1 gene is located on chromosome 22q11.2. It encodes the enzyme, which is involved in conjugation of reduced glutathione to various electrophiles and hydrophobic compounds [2]. Ultimately, toxic substrates may be removed from the body. The absence of GSTT1 gene, also known as homozygous deletion or null genotype and herein referred to as GSTT1-absent, has been reported with varying frequencies in different populations [3]. The carriers of GSTT1-absent genotype are unable to metabolize specific mutagenic carcinogens [4]. The deletion has been correlated with ovarian, bladder, colon, oral, lung and pediatric cancers among different populations [5-10]. It is a candidate genetic markers for cancer risk, prognosis, and treatment response. The independent contribution of GSTT1 null genotype to breast cancer susceptibility, tumour characteristics, and response to prescribed regimens remains inconclusive in different populations across the world [11-13].

In Pakistan, the age-standardized rate (ASR) of the female breast cancer incidence is among the highest in Asia (43.9 per 100,000), whereas the mortality rate is one of the highest in the world $(23.2$ per 100,000) $[14,15]$.

Two previous studies from Pakistan $[16,17]$ report an independent lack of association between absence of GSTT1 gene and breast cancer susceptibility. Both the studies were published from the Punjab area. Furthermore, the small sample size, and conflicting frequencies in controls: 
$18.7 \%$ [16] vs $31.4 \%$ (erroneously reported as $16 \%$ in the study) [17] limit the applicability of drawn conclusions.

The prospective observational molecular study was designed based on the biological plausibility of GSTT1 deletion in carcinogenesis. It addresses the paucity and contradiction in the available data from a region that has frequent and aggressive breast tumors. The first component of the study, the case-control analysis, evaluated the contribution of GSTT1 gene in breast cancer risk. Simultaneously, the second part comprising case series analysis investigated the contribution of GSTT1 genotypes in selected tumour characteristics and breast cancer survival after standard treatment.

\section{Materials and methods}

\section{Study design and participant enrollment}

The overall study schema is shown in Fig 1.

The patients were recruited from $\underline{\text { Atomic }}$ Energy Medical $\underline{\text { Centre }}$ (AEMC), innah $\underline{\text { Postgraduate }}$

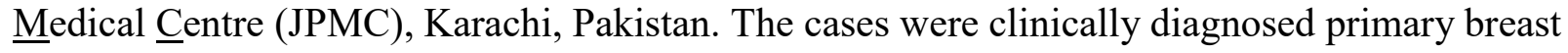
cancer patients. The cases underwent radiotherapy at the aforementioned participating institution following chemotherapy and surgery, which were carried out at hospitals other than AEMC. The details of control enrolment have been published elsewhere [18], with the modification of inclusion of only samples from age-matched ( $\geq 18$ years), female participants in the present study. All the subjects were recruited at Karachi, Pakistan and therefore, the distribution of ethnicities was the same in cases and controls (Sindhi, a self-defined Urdu-speaking ethnicity, Pathan, and Punjabi were the main ethnic groups). The research involved human participants and followed the provisions of Declaration of Helsinki and its amendments. Research protocols were approved by the independent Ethics Review Committees of all the relevant institutions. The 
medRxiv preprint doi: https://doi.org/10.1101/2021.02.18.21252044; this version posted February 23, 2021. The copyright holder for this preprint (which was not certified by peer review) is the author/funder, who has granted medRxiv a license to display the preprint in perpetuity.

All rights reserved. No reuse allowed without permission.

study follows the reporting recommendations for tumor marker prognostic studies (REMARK) $[19,20]$ (Supplementary Table 1).

\section{Data collection}

Information regarding age was recorded from all the participants. In patients, tumor node metastasis (TNM) staging and histological grading were carried out according to the Union Internationale Contre le Cancer (UICC) recommendations [21]. Data pertaining to tumour characteristics (tumour stage, grade, and size) and histology were obtained from the patients' hospital medical files. The information for the included parameters was documented in majority of the hospital records, unlike other parameters associated with breast cancers, for e.g. hormonal status, and Bloom Richardson grading system etc. Three-year survival data were collected through telephonic follow-up. The missing information is due to: (i) return of patients to their own towns/villages after treatment at Karachi; (ii) erroneous contact information; (iii) and no response.

\section{Sample collection and DNA extraction}

All the participants volunteered $8-10 \mathrm{ml}$ of venous blood sample, which was collected in ACDcoated vacutainers (BD Vacutainer ${ }^{\circledR}$ BD Franklin Lakes NJ USA). Samples from the cases were collected at the time of radiotherapy, post-mastectomy and chemotherapy treatment. The blood samples were either processed immediately or stored at $4^{\circ} \mathrm{C}$ until DNA extraction.

DNA was extracted from the white blood cells according to the standard phenol-chloroform method [22]. It was quantified spectrophotometrically (Beckman Coulter ${ }^{\mathrm{TM}} \mathrm{DU}^{\circledR}$ 530). The quality control cut-off for 260/280 ratio was between 1.7-1.99. DNA quality was also analyzed by $0.7 \%$ agarose gel electrophoresis followed by UV visualization using a gel imaging system 
(Azure $\mathrm{c} 300^{\circledR}$ biosystems). No fragmentation or smearing was observed in any of the samples (Fig 2).

The working dilutions for experiments were prepared at room temperature and stored at $4^{\circ} \mathrm{C}$. The stock DNA samples were stored at $-20^{\circ} \mathrm{C}$.

\section{Genotyping:}

Cases: GSTT1 genotyping was carried out by a multiplex polymerase chain reaction (PCR) with $\beta$-globin as an amplification control. The primer sequences have been published earlier [17]. PCR was carried out with Taq DNA polymerase kit (Thermofisher Scientific Inc.). Total PCR reaction mix $(10 \mu \mathrm{l})$ consisted of $1 \mathrm{X}$ PCR buffer, $0.9 \mathrm{mM} \mathrm{MgCl}_{2}, 0.5 \mathrm{mM}$ dNTPs, $1.5 \mathrm{U} / \mu \mathrm{l} \mathrm{Taq}$ polymerase, $1.8 \mu \mathrm{M}$ primers each for GSTT1 and $\beta$-globin genes, and 70ng DNA. The PCR conditions were: initial denaturation at $94^{\circ} \mathrm{C}$ for 5 minutes, followed by 40 cycles of: $94^{\circ} \mathrm{C}$ for 45 seconds, annealing at $60^{\circ} \mathrm{C}$ for 45 seconds, and extension at $72^{\circ} \mathrm{C}$ for 45 seconds. Final extension was carried at $72^{\circ} \mathrm{C}$ for 5 minutes. Amplicons were analyzed under UV on $2 \%$ agarose gel, which was stained with ethidium bromide. A fragment of 473bp indicated GSTT1-present genotype. GSTT1-absent genotype did not show this amplification. The amplification of $\beta$-globin gene served as the control for successful PCR. A negative control was included in all the genotyping experiments (Fig. 3).

The results of genotyping were confirmed by double blind evaluation, inclusion of replicates, and negative controls.

Controls: The genotyping in controls has been described earlier [18]. It differentiates between homozygous GSTT1-present, heterozygous GSTT1-present/absent, and homozygous GSTT1absent. In the final observation, GSTT1-present allele was determined by an amplicon of 466bp, while GSTT-absent allele was identified by an amplicon of 1,460bp. 


\section{Treatment of breast cancer patients:}

All the participating cases underwent mastectomy, adjuvant chemotherapy, and/or radiotherapy. Before the start of chemotherapy, echocardiography was done to assess cardiac function (ejection fraction cut-off for start of doxorubicin based chemo was $>55 \%$ ). A test dose of docitaxel was given to rule out hypersensitivity before $1^{\text {st }}$ cycle. Neurological assessment was done during taxane (paclitaxel) cycles. Chemotherapy related toxicities were assessed after every

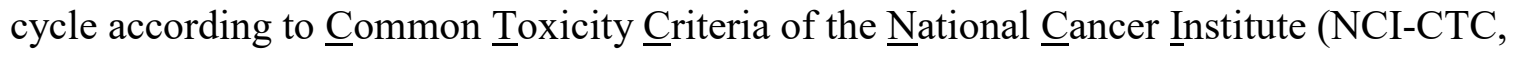
version 2.0) [23]. The "severe toxicity" was defined as hematological or gastrointestinal toxicity of grade $3-4$.

The followed chemotherapy regimen was: Adriamycin-Cyclophosphamide $\mathrm{x} 4$ followed by taxane $\mathrm{x} 4$ (docitaxel or paclitaxel): Doxorubicin $60 \mathrm{mg} / \mathrm{m}^{2}$ on day 1 , cyclophosphamide $600 \mathrm{mg}$ on day 1 , paclitaxel $175 \mathrm{mg} / \mathrm{m}^{2}$ on day 1 OR docitaxil $100 \mathrm{mg} / \mathrm{m}^{2}$ on day 1 . Repeated every 3 weeks.

Complete blood count, liver function test, and renal function test were carried out to assess the treatment response.

\section{Statistical analysis}

The allele distribution for GSTT1 polymorphism in controls was assessed for Hardy-Weinberg equilibrium [24]. The statistical tests for association analysis were carried out by using Statistical Package for Social Science (SPSS) for Windows v.19.0 (SPSS, Inc., Chicago, Illinois, USA) and online OpenEpi software [25]. In case-control investigations, data for GSTT1 genotype was obtained for all the participants, except two cases where no amplification was recorded. The agematching between cases and controls was analyzed by Student's t-test for independent samples with the assumption of unequal variances. To achieve $80 \%$ power at a two-sided level of 
significance, various odds ratios (OR) of genetic risk due to GSTT1 polymorphism for breast cancers were calculated. Accrual of 260 participants (matched cases and controls) allows the identification of $\mathrm{OR} \geq 2$ for GSTT1 variation with the GSTT1-absent frequency of 0.24 (the median value of the reported prevalence in controls from Pakistan [16-18, 26-37] was used for the calculations [38]).

The missing information for case series analysis is itemized in the relevant results section. The primary objective was the investigation of GSTT1 polymorphism association/s with breast cancer susceptibility, the selected clinical parameters, and survival. The data were assessed by Pearson $\chi^{2}$ test. The OR were tabulated with $95 \%$ confidence interval $(95 \% \mathrm{CI})$ to evaluate the strength of the associations. The overall survival (OS) and hazard ratios (HR) with 95\% CI were assessed by Kaplan-Meier method using MedCalc software v.19.2.6 [39, 40]. In all the statistical tests, p-values $<0.05$ were considered to be significant.

\section{Results}

\section{Participants' information and clinical data of patients}

Total number of patients diagnosed with primary breast cancer disease was 121 , whereas the total number of age- and gender-matched controls was 143. Characteristics of the 264 participants included in the study are presented in Table 1.

Mean age of the patients was $44.48 \pm 0.95$ years, whereas for the controls, the mean age was $45.62 \pm 0.58$ years. All patients presented with invasive ductal carcinoma (IDC) of the breast. Majority of the patients had advanced tumor stage (stages III and IV; $p$-value: $0.024^{* *}$ ), tumour size of $>2 \mathrm{~cm}\left(p\right.$-value: $\left.<0.01^{* *}\right)$, and high tumour grade (grades 3 and $4 ; p$-value: $\left.>0.05\right)$. 
medRxiv preprint doi: https://doi.org/10.1101/2021.02.18.21252044; this version posted February 23, 2021. The copyright holder for this preprint

(which was not certified by peer review) is the author/funder, who has granted medRxiv a license to display the preprint in perpetuity.

All rights reserved. No reuse allowed without permission.

\section{Association between GSTT1 polymorphism and breast cancer risk}

Allelic and genotypic frequencies of GSTT1 polymorphism in controls are shown in Table 2. The proportions were in Hardy-Weinberg equilibrium.

Associations between the GSTT1 genotypes and breast cancer susceptibility are presented in Table 3.

The comparison of GSTT1-present genotype with GSTT1-absent genotype in cases and controls revealed that GSTT1-absent genotype was significantly associated with risk for breast cancers ( $p$ value: 0.003$)$. The OR were 2.13 (95\% CI: 1.08 - 4.29).

\section{Association between GSTT1 polymorphism and specific tumour characteristics:}

In case series analysis, the present study does not report any statistically significant association between the absence of GSTT1 gene and the studied tumour characteristics, i.e., stage, grade, and size. The $p$-values were $0.12,0.32$, and 0.07 , respectively.

\section{Association of the GSTT1 polymorphism and OS in breast cancer patients:}

As shown in Table 4 and Fig 4, GSTT1-present carriers had 10 months' longer survival (mean OS: 33 months; 95\% CI: 30.96-34.65) than those with GSTT1-absent genotype (mean OS: 23 months; 95\% CI 17.90-28.59); $p$-value: 0.0001. The HR with 95\% CI for OS in patients carrying GSTT1-absent genotype was 8.13 (2.91-22.96) with GSTT1-present genotype as the reference variable.

\section{Discussion:}

In the present study, we evaluated the association of GSTT1 genotypes with breast cancer-related parameters. We report a GSTT1-absent frequency of $11 \%$ in the controls, which is in agreement with couple of earlier studies published from the region, one from Islamabad [33], and the other from Karachi [18]. In this study, we report a significant association of GSTT1-absent genotype 
with increased breast cancer risk in a representative sample from Pakistani population. The OR were 2.13 (95\% CI: $1.08-4.29)$. We also report a significant difference in the survival duration

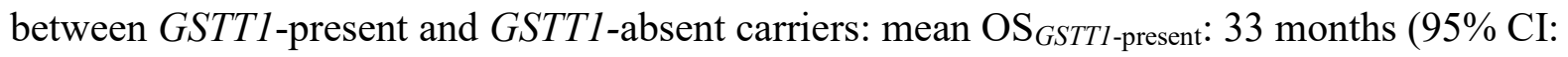

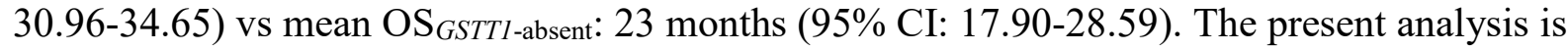
the first report of such population-specific associations between GSTT1 genotypes and specific factors associated with breast cancers.

The incidence of breast cancers varies across the globe. The highest estimated age-standardized incidence rates are reported from Belgium (113.2 per 100,000), while the lowest are reported from Bhutan (5.0 per 100.000). Furthermore, the highest estimated age-standardized mortality rates are reported from Fiji $(36.9$ per 100,000) while the lowest are reported from Bhutan $(2.7$ per 100,000) [15]. The known risk factors such as age, family history, different reproductive parameters, and obesity account for only one-third of the risk for breast cancers $[11,41]$. In addition, the reason(s) for high mortality rates across certain populations need to be determined [42-44].

It is likely that a number of genes are involved, with the possibility of gene-environment interactions, in breast cancer etiology, progression, and response to treatment [45]. The quantitative contributions of such genes remain to be delineated across different populations and regions.

A proposed mechanism of carcinogenesis due to loss of function of GSTT1 isoenzyme is shown in Fig 5. The exogenous and endogenous carcinogens are not metabolized to non-toxic components. Consequently, tumourigenesis and/or tumour progression are likely to occur [4]. In addition, chemotherapeutic agents may also be metabolized by the pathways involving GSTT1, 
rendering the patients with GSTT1-present genotype irresponsive to either therapy or specific doses of therapy.

Among different populations, the loss-of-function polymorphism in GSTT1 encoding gene occurs with varying frequencies [46]. Null genotype is correlated with vulnerability to cancers, tumour characteristics, and differences in treatment response [1, 47].

The examples of low and high frequencies of GSTT1-absent genotype across different global regions are listed in Table 5.

In Pakistan, the frequency of GSTT1 null genotype in healthy individuals has been reported in the range of $0.06-0.24$ [16-18, 27-37]. This wide range may be attributed to limited sample sizes, population admixture and differences in methodologies. Similarly, variations in the frequency of this genotype in breast cancer patients from Pakistan have been reported: 8\% [16] and $27 \%$ (erroneously reported as $49 \%$ in the text) [17]. Here we report a frequency of $21 \%$. In contrast to the studies conducted in Punjab/Central Pakistan $[16,17]$, the present study was carried out in Southern-Pakistan, where majority of the patients belonged to Sindhi and a selfdefined Urdu-Speaking ethnicities (25\% each).

Our case-control analysis is in agreement with a number of studies reported from different parts of the world $[11,59]$.

The present study is the only association analysis report of the GSTT1-absent genotype with selected clinical parameters in breast cancers from this region. It is the first report of significant association of GSTT1-absent genotype with decreased OS in primary breast cancer patients. An earlier study from China reported such an association with untreated metastatic breast cancers [60]. 
medRxiv preprint doi: https://doi.org/10.1101/2021.02.18.21252044; this version posted February 23, 2021. The copyright holder for this preprint (which was not certified by peer review) is the author/funder, who has granted medRxiv a license to display the preprint in perpetuity.

All rights reserved. No reuse allowed without permission.

The strength of our study is the underlying unique population, where molecular data for breast cancer risk and clinical parameters is scarce. The limitations of the study are sample size and the dearth of information for known risk-factors and clinical parameters, primarily due to restriction of resources in the healthcare. The present study highlights the importance of conducting rigorous molecular epidemiology studies in order to devise evidence-based better strategies in breast cancer management, particularly in resource-limited settings.

\section{Conclusions:}

In conclusion, the significant contribution of GSTT1-absent genotype to the breast cancer risk in Pakistani population is reported for the first time in literature. A unique finding of this study was the association of this genotype with significantly shorter OS in breast cancer patient post standard treatment, which has not been reported earlier. These observations are biologically plausible. If validated further through multiple center studies and larger sample sizes, absence of GSTT1 gene could serve as a risk and survival marker in breast cancers, at least in specific population.

Acknowledgments: We would like to thank the participants in the study.

\section{Compliance with ethical standards}

Funding: No funding was received for this study

Conflict of interest Each authors declares no conflict of interest

Ethical approval The protocol was approved by the ethics review committees of the participating institutions: International Center for Chemical and Biological Sciences (ICCBS), University of Karachi, Karachi, Pakistan [ICCBS/IEC-016-BS/HT-2016/Protocol/1.0]; Atomic Energy Medical Centre (AEMC), Jinnah Postgraduate Medical Centre (JPMC), Karachi, Pakistan [Admin-3 (257)/2016]; Sindh Institute of Urology and Transplantation (SIUT), Karachi, 
medRxiv preprint doi: https://doi.org/10.1101/2021.02.18.21252044; this version posted February 23, 2021. The copyright holder for this preprint (which was not certified by peer review) is the author/funder, who has granted medRxiv a license to display the preprint in perpetuity.

All rights reserved. No reuse allowed without permission.

Pakistan [18]. The study was conducted according to the Declaration of Helsinki and its further amendments.

Participants' consent The participants discussed the informed consent with researchers and the voluntary enrollment in the study was documented by either signing of the written consent forms or using the thumb impressions.

\section{REFERENCES}

1. Allocati N, Masulli M, Di Ilio C, Federici L (2018). Glutathione transferases: substrates, inihibitors and pro-drugs in cancer and neurodegenerative diseases. Oncogenesis 7(1), 115. https://doi.org/10.1038/s41389-017-0025-3

2. Webb G, Vaska V, Coggan M, Board P (1996). Chromosomal localization of the gene for the human theta class glutathione transferase (GSTT1). Genomics 33(1), 121-123. https://doi.org/10.1006/geno.1996.0167

3. Kassogue Y, Diakite B, Kassogue O, Konate I, Tamboura K, Diarra Z, Dehbi H, Nadifi S, Traore CB, Dao S, Doumbia S (2020) Genetic polymorphism of drug metabolism enzymes (GSTM1, GSTT1 and GSTP1) in the healthy Malian population. Mol Biol Rep 47(1):393-400. https://doi.org/10.1007/s11033-019-05143-5

4. Josephy PD (2010) Genetic variations in human glutathione transferase enzymes: significance for pharmacology and toxicology. Hum Genomics and Proteomics: HGP. 2010 2010:876940. https://doi:10.4061/2010/876940

5. Howells RE, Redman CW, Dhar KK, Sarhanis P, Musgrove C, Jones PW, Alldersea J, Fryer AA, Hoban PR, Strange RC (1998) Association of glutathione S-transferase GSTM1 and GSTT1 null genotypes with clinical outcome in epithelial ovarian cancer. Clin Canc Res 4(10):2439-2445. 
medRxiv preprint doi: https://doi.org/10.1101/2021.02.18.21252044; this version posted February 23, 2021. The copyright holder for this preprint (which was not certified by peer review) is the author/funder, who has granted medRxiv a license to display the preprint in perpetuity.

All rights reserved. No reuse allowed without permission.

6. Zhou T, Li HY, Xie WJ, Zhong Z, Zhong H, Lin ZJ (2018) Association of Glutathione Stransferase gene polymorphism with bladder Cancer susceptibility. BMC Cancer 18(1):1088. https://doi.org/10.1186/s12885-018-5014-1

7. Qin XP, Zhou Y, Chen Y, Li NN, Chen B, Yang P, Wu XT (2013) Glutathione Stransferase T1 gene polymorphism and colorectal cancer risk: An updated analysis. Clin Research Hepatol Gastroenterol. 37(6):626-635. https://doi.org/10.1016/j.clinre.2013.04.007

8. Zhang ZJ, Hao K, Shi R, Zhao G, Jiang GX, Song Y, Xu X, Ma J (2011) Glutathione Stransferase M1 (GSTM1) and glutathione S-transferase T1 (GSTT1) null polymorphisms, smoking, and their interaction in oral cancer: a HuGE review and meta-analysis. Am J Epidemiol 173(8):847-857. https://doi.org/10.1093/aje/kwq480

9. Yang X, Qiu MT, Hu JW, Wang XX, Jiang F, Yin R, Xu L (2013) GSTT1 null genotype contributes to lung cancer risk in asian populations: a meta-analysis of 23 studies. PloS one 8(4):e62181. https://doi.org/10.1371/journal.pone.0062181

10. Lopes BA, Emerenciano M, Gonçalves BA, Vieira TM, Rossini A, Pombo-de-Oliveira MS (2015) Polymorphisms in CYP1B1, CYP3A5, GSTT1, and SULT1A1 are associated with early age acute leukemia. PloS one10(5):e0127308.

https://doi.org/10.1371/journal.pone.0127308

11. Miao LF, Ye XH, He XF (2020) Individual and combined effects of GSTM1, GSTT1, and GSTP1 polymorphisms on breast cancer risk: A meta-analysis and re-analysis of systematic meta-analyses. PloS one 15(3):e0216147.

https://doi.org/10.1371/journal.pone.0216147 
medRxiv preprint doi: https://doi.org/10.1101/2021.02.18.21252044; this version posted February 23, 2021. The copyright holder for this preprint (which was not certified by peer review) is the author/funder, who has granted medRxiv a license to display the preprint in perpetuity.

All rights reserved. No reuse allowed without permission.

12. Wang J, Wang T, Yin GY, Yang L, Wang ZG, Bu XB (2015) Glutathione S-transferase polymorphisms influence chemotherapy response and treatment outcome in breast cancer. Genet Mol Res. 14(3):11126-11132.

http://dx.doi.org/10.4238/2015.September.22.6

13. Bansal VK, Rajan K, Sharma A, Paliwal P, Chaubal G, Jindal V, Misra MC, Kucheria K (2015). Prospective case-control study to evaluate the role of glutathione s transferases (GSTT1 and GSTM1) gene deletion in breast carcinoma and its prognostic significance. Indian J of Surg 77(3):1067-1072. https://doi.org/10.1007/s12262-014-1152-0

14. Badar F, Mahmood S, Yusuf MA, Sultan F (2016) Epidemiology of cancers in Lahore, Pakistan, 2010-2012: a cross-sectional study. BMJ open 6(6):e011828.

\section{http://dx.doi.org/10.1136/bmjopen-2016-011828}

15. Ferlay J, Soerjomataram I, Ervik M, Dikshit R, Eser S, Mathers C, Rebelo M, Parkin DM, Forman D, Bray F (2013) GLOBOCAN 2012 v1. 0, Cancer incidence and mortality worldwide: IARC CancerBase No. 11. International Agency for Research on Cancer, Lyon, France. globocan. iarc. fr. 2018. https://gco.iarc.fr/today/online-analysis-map. Accessed 18 May 2020

16. Nosheen M, Malik FA, Kayani MA (2011) Lack of influence of glutathione S-transferase gene deletions in sporadic breast cancer in Pakistan. Asian Pac J Cancer Prev 12(7):17491752.

17. Sohail A, Kanwal N, Ali M, Sadia S, Masood AI, Ali F, Iqbal F, Crickmore N, Shaikh RS, Sayyed AH (2013) Effects of glutathione-S-transferase polymorphisms on the risk of breast cancer: A population-based case-control study in Pakistan. Environ Toxicol Pharmacol 35(2):143-153. https://doi.org/10.1016/j.etap.2012.11.014 
medRxiv preprint doi: https://doi.org/10.1101/2021.02.18.21252044; this version posted February 23, 2021. The copyright holder for this preprint (which was not certified by peer review) is the author/funder, who has granted medRxiv a license to display the preprint in perpetuity.

All rights reserved. No reuse allowed without permission.

18. Abid A, Ajaz S, Khan AR, Zehra F, Hasan AS, Sultan G, Mohsin R, Hashmi A, Niamatullah N, Rizvi SA, Mehdi SQ (2016) Analysis of the glutathione S-transferase genes polymorphisms in the risk and prognosis of renal cell carcinomas. Case-control and meta-analysis. Urol Oncol 34(9):419-e1. https://doi.org/10.1016/j.urolonc.2016.04.005

19. McShane LM, Altman DG, Sauerbrei W, Taube SE, Gion M, Clark GM (2006) REporting recommendations for tumor MARKer prognostic studies (REMARK). Breast Cancer Res Treat 100(2):229-235. https://doi.org/10.1007/s10549-006-9242-8

20. Sauerbrei W, Taube SE, McShane LM, Cavenagh MM, Altman DG (2018) Reporting recommendations for tumor marker prognostic studies (REMARK): an abridged explanation and elaboration. J Natl Cancer Inst 110(8):803-811.

https://doi.org/10.1093/jnci/djy088

21. Sobin LH, Gospodarowicz MK, Wittekind C, editors (2011) TNM classification of malignant tumours. John Wiley \& Sons

22. Sambrook J, Russell DW (2001) Molecular cloning. A laboratory manual. New York: Cold Spring Harbor Laboratory

23. National Cancer Institute-Cancer Therapy Evaluation Program: Common Toxicity Criteria. Version 2.0 (1999) http://ctep.info.nih.gov

24. Michael C (2008) A simple calculator to determine whether observed genotype frequencies are consistent with Hardy-Weinberg equilibrium. http://www.tufts. edu/ $\underline{\text { mcourt01/Documents. Courtlab-HW calculator.xls }}$

25. Dean AG, Sullivan KM, Soe MM (2013) OpenEpi: open source epidemiologic statistics for public health, version. https://www.openepi.com/Menu/OE_Menu.htm 
medRxiv preprint doi: https://doi.org/10.1101/2021.02.18.21252044; this version posted February 23, 2021. The copyright holder for this preprint (which was not certified by peer review) is the author/funder, who has granted medRxiv a license to display the preprint in perpetuity.

All rights reserved. No reuse allowed without permission.

26. Dar A, Faryal R, Masood N (2015) Possible association of a distinct combined Glutathione-S-transferase members with allergic asthma patients in Pakistan. Genes Dis 4(2):111-115. https://doi.org/10.1016/j.gendis.2017.01.001

27. Hasan S, Hameed A, Saleem S, Shahid SM, Haider G, Azhar A (2015) The association of GSTM1 and GSTT1 polymorphisms with squamous cell carcinoma of cervix in Pakistan. Tumour Biol 36(7):5195-5199. https://doi.org/10.1007/s13277-015-3175-y

28. Khan MI, Micheal S, Akhtar F, Ahmed W, Ijaz B, Ahmed A, Qamar R (2010) The association of glutathione S-transferase GSTT1 and GSTM1 gene polymorphism with pseudoexfoliative glaucoma in a Pakistani population. Mol Vis 16:2146-2152. PMID: $\underline{21151336}$

29. Malik SS, Masood N, Yasmin A (2015) Prostate cancer and glutathione S-transferase deletions. EXCLI J 14:1049-1054. https//doi.org/10.17179/excli2015-192

30. Masood N, Kayani MA (2013) Protection against laryngeal and pharyngeal carcinoma: Heterozygous vs. homozygous deletions of GSTM1 and GSTT1. Genet Mol Biol 36(1):1-6. https://doi.org/10.1590/S1415-47572013005000006

31. Nabgha EA, Eqani S, Khuram F, Alamdar A, Tahir A, Shah STA, Nasir A, Javed S, Bibi N, Hussain A, Rasheed H, Shen H (2020) Environmental exposure pathway analysis of trace elements and autism risk in Pakistani children population. Sci Total Environ 712:136471. https://doi.org/10.1016/j.scitotenv.2019.136471

32. Nosheen M, Ishrat M, Malik FA, Baig RM, Kayani MA (2010) Association of GSTM1 and GSTT1 gene deletions with risk of head and neck cancer in Pakistan: a case control study. Asian Pac J Cancer Prev 1(4):881-885. PMID: 21133595 
medRxiv preprint doi: https://doi.org/10.1101/2021.02.18.21252044; this version posted February 23, 2021. The copyright holder for this preprint (which was not certified by peer review) is the author/funder, who has granted medRxiv a license to display the preprint in perpetuity.

All rights reserved. No reuse allowed without permission.

33. Rehman S, Ahmed P, Saba N, Munir S, Sajjad S, Satti TM, Chaudry QU, Mansoor A (2015) Association of GSTM1 and GSTT1 deletion polymorphisms with Pakistani aplastic anemia patients and controls and meta-analysis. Ann Hematol 94(12):1965-1971. https://doi.org/10.1007/s00277-015-2482-0

34. Shaikh RS, Amir M, Masood AI, Sohail A, Athar HU, Siraj S, Ali M, Anjam MS (2010) Frequency distribution of GSTM1 and GSTT1 null allele in Pakistani population and risk of disease incidence. Environ Toxicol Pharmacol 30(1):76-79.

\section{https://doi.org/10.1016/j.etap.2010.04.002}

35. Zakiullah, Ahmadullah, Khisroon M, Saeed M, Khan A, Khuda F, Ali S, Javed N, Ovais M, Masood N, Khalil NK, Ismail M (2015) Genetic susceptibility to oral cancer due to combined effects of GSTT1, GSTM1 and CYP1A1 gene variants in tobacco addicted patients of Pashtun ethnicity of Khyber Pakhtunkhwa province of Pakistan. Asian Pac J Cancer Prev 16(3):1145-1150. http://doi.org/10.7314/apjcp.2015.16.3.1145.

36. Zakiullah, Saeed M, Javed N, Khuda F, Ovais M (2019) Association of nasopharyngeal cancer risk with genetic polymorphisms of drug-metabolizing enzyme genes GSTM1, GSTT1 and CYP1A1 (rs4646903 variant), in tobacco addicted patients of Pashtun ethnicity of Khyber Pakhtunkhwa Province of Pakistan. Pak J Pharm Sci 32(5):210721016. PMID: 31813877

37. Zehra A, Zehra S, Ismail M, Azhar A (2018) Glutathione S-Transferase M1 and T1 Gene Deletions and Susceptibility to Acute Lymphoblastic Leukemia (ALL) in adults. Pak J Med Sci 34(3):666-670. https://doi.org/10.12669/pjms.343.14911

38. Schlesselman JJ (1982) Case-control studies: design, conduct, analysis. Oxford University Press 
medRxiv preprint doi: https://doi.org/10.1101/2021.02.18.21252044; this version posted February 23, 2021. The copyright holder for this preprint (which was not certified by peer review) is the author/funder, who has granted medRxiv a license to display the preprint in perpetuity.

All rights reserved. No reuse allowed without permission.

39. Schoonjans FR, Zalata A, Depuydt CE, Comhaire FH (1995) MedCalc: a new computer program for medical statistics. Comput Methods Programs Biomed 48(3):257-262. https://doi.org/10.1016/0169-2607(95)01703-8

40. MedCalc Version 19.2.6 Software: https://www.medcalc.org/. Accessed 11 May 2020

41. Ng EH, Gao F, Ji CY, Ho GH, Soo KC (1997) Risk factors for breast carcinoma in Singaporean Chinese women: the role of central obesity. Cancer 80(4):725-731. https:doi.org/10.1002/(sici)1097-0142(19970815)80:4<725::aid-cncr11>3.0.co;2-v

42. De Angelis R, Sant M, Coleman MP, Francisci S, Baili P, Pierannunzio D, Trama A, Visser O, Brenner H, Ardanaz E, Bielska-Lasota M (2014) Cancer survival in Europe 1999-2007 by country and age: results of EUROCARE-5 - a population-based study. Lancet Oncol 15(1):23-34. https://doi.org/10.1016/S1470-2045(13)70546-1

43. Allemani C, Weir HK, Carreira H, Harewood R, Spika D, Wang XS, Bannon F, Ahn JV, Johnson CJ, Bonaventure A, Marcos-Gragera R (2015) Global surveillance of cancer survival 1995-2009: analysis of individual data for 25676887 patients from 279 population-based registries in 67 countries (CONCORD-2). Lancet 385(9972):977-1010. https://doi.org/10.1016/S0140-6736(14)62038-9

44. Huang Z, Wen W, Zheng Y, Gao YT, Wu C, Bao P, Wang C, Gu K, Peng P, Gong Y, Zhang M (2016) Breast cancer incidence and mortality: trends over 40 years among women in Shanghai, China. Ann Oncol 27(6):1129-1134. https://doi.org/10.1093/annonc/mdw069

45. Lauby-Secretan B, Scoccianti C, Loomis D, Benbrahim-Tallaa L, Bouvard V, Bianchini F, Straif K (2015) Breast-cancer screening_viewpoint of the IARC Working Group. N Engl J Med 372(24):2353-8. https://doi.org/10.1056/NEJMc1508733 
medRxiv preprint doi: https://doi.org/10.1101/2021.02.18.21252044; this version posted February 23, 2021. The copyright holder for this preprint (which was not certified by peer review) is the author/funder, who has granted medRxiv a license to display the preprint in perpetuity.

All rights reserved. No reuse allowed without permission.

46. Saitou M, Ishida T (2015) Distributions of the GSTM1 and GSTT1 null genotypes worldwide are characterized by latitudinal clines. Asian Pac J Cancer Prev 16(1):355361. https://doi.org/ 10.7314/apjcp.2015.16.1.355

47. Ludovini V, Antognelli C, Rulli A, Foglietta J, Pistola L, Eliana R, Floriani I, Nocentini G, Tofanetti FR, Piattoni S, Minenza E (2017) Influence of chemotherapeutic drugrelated gene polymorphisms on toxicity and survival of early breast cancer patients receiving adjuvant chemotherapy. BMC Cancer 17(1):502.

https://doi.org/10.1186/s12885-017-3483-2

48. Lakhdar R, Denden S, Knani J, Leban N, Daimi H, Hassine M, Lefranc G, Chibani JB, Khelil AH (2010) Association of GSTM1 and GSTT1 polymorphisms with chronic obstructive pulmonary disease in a Tunisian population. Biochem Genet 48(7-8):647657. https://doi.org/10.1007/s10528-010-9346-Z

49. Kirk GD, Turner PC, Gong Y, Lesi OA, Mendy M, Goedert JJ, Hall AJ, Whittle H, Hainaut P, Montesano R, Wild CP (2005) Hepatocellular carcinoma and polymorphisms in carcinogen-metabolizing and DNA repair enzymes in a population with aflatoxin exposure and hepatitis B virus endemicity. Cancer Epidemiol Prev Biomarkers 14(2):373-379. https://doi.org.10.1158/1055-9965.EPI-04-0161

50. Gutiérrez-Amavizca BE, Orozco-Castellanos R, Ortíz-Orozco R, Padilla-Gutiérrez J, Valle Y, Gutiérrez-Gutiérrez N, García-García G, Gallegos-Arreola M, Figuera LE (2013) Contribution of GSTM1, GSTT1, and MTHFR polymorphisms to end-stage renal disease of unknown etiology in Mexicans. Indian J Nephrol 23(6):438.

https://doi.org/10.4103/0971-4065.120342 
medRxiv preprint doi: https://doi.org/10.1101/2021.02.18.21252044; this version posted February 23, 2021. The copyright holder for this preprint (which was not certified by peer review) is the author/funder, who has granted medRxiv a license to display the preprint in perpetuity.

All rights reserved. No reuse allowed without permission.

51. Gaspar PA, Hutz MH, Salzano FM, Hill K, Hurtado AM, Petzl-Erler ML, Tsuneto LT, Weimer TA (2002) Polymorphisms of CYP1a1, CYP2e1, GSTM1, GSTT1, and TP53 genes in Amerindians. Am J Phys Anthropol 119(3):249-256.

https://doi.org/10.1002/ajpa.10128

52. Huang K, Sandler RS, Millikan RC, Schroeder JC, North KE, Hu J (2006) GSTM1 and GSTT1 polymorphisms, cigarette smoking, and risk of colon cancer: a population-based case-control study in North Carolina (United States). Cancer Causes Control 17(4):385394. https://doi.org/ 10.1007/s10552-005-0424-1

53. Dialyna IA, Arvanitis DA, Spandidos DA (2001) Genetic polymorphisms and transcriptional pattern analysis of CYP1A1, AhR, GSTM1, GSTP1 and GSTT1 genes in breast cancer. Int J Mol Med 8(1):79-87. https://doi.org/ 10.3892/ijmm.8.1.79

54. Piacentini S, Polimanti R, Porreca F, Martínez-Labarga C, De Stefano GF, Fuciarelli M (2011) GSTT1 and GSTM1 gene polymorphisms in European and African populations. Mol Biol Rep 38(2):1225-1230. https://doi.org/10.1007/s11033-010-0221-0

55. Karban A, Krivoy N, Elkin H, Adler L, Chowers Y, Eliakim R, Efrati E (2011) NonJewish Israeli IBD patients have significantly higher glutathione S-transferase GSTT1null frequency. Dig Dis Sci 56(7):2081-7. https://doi.org/10.1007/s10620-010-1543-4

56. Saify K, Saadat I, Saadat M (2012) Genetic polymorphisms of glutathione S-transferase T1 (GSTT1) and M1 (GSTM1) in selected populations of Afghanistan. Mol Biol Rep 39(8):7855-7859. https://doi.org/10.1007/s11033-012-1628-6

57. Uhm YK, Yoon SH, Kang IJ, Chung JH, Yim SV, Lee MH (2007) Association of glutathione S-transferase gene polymorphisms (GSTM1 and GSTT1) of vitiligo in Korean population. Life Sci 81(3):223-227. https://doi.org/ 10.1016/j.1fs.2007.05.006 
medRxiv preprint doi: https://doi.org/10.1101/2021.02.18.21252044; this version posted February 23, 2021. The copyright holder for this preprint (which was not certified by peer review) is the author/funder, who has granted medRxiv a license to display the preprint in perpetuity.

All rights reserved. No reuse allowed without permission.

58. Spurdle AB, Chang JH, Byrnes GB, Chen X, Dite GS, McCredie MR, Giles GG, Southey MC, Chenevix-Trench G, Hopper JL (2007) A systematic approach to analysing genegene interactions: polymorphisms at the microsomal epoxide hydrolase EPHX and glutathione S-transferase GSTM1, GSTT1, and GSTP1 loci and breast cancer risk. Cancer Epidemiol Prev Biomarkers 16(4):769-774. https://doi.org/10.1158/10559965.EPI-06-0776

59. Strange RC, Matharoo B, Faulder GC, Jones P, Cotton W, Elder JB, Deakin M (1991) The human glutathione S-transferases: a case-control study of the incidence of the GST1 0 phenotype in patients with adenocarcinoma. Carcinogenesis 12(1):25-28. https://doi.org/10.1093/carcin/12.1.25

60. Zhang J, Wu Y, Hu X, Wang B, Wang L, Zhang S, Cao J, Wang Z (2017) GSTT1, GSTP1, and GSTM1 genetic variants are associated with survival in previously untreated metastatic breast cancer. Oncotarget 8(62):105905-105914.

https://doi.org/10.18632/oncotarget.22450

\section{Contributions:}

Conceptualization: SA

Participant enrollment/Data collection: SA, SZZ, SMA, AS, MAM, AA, SF, SK

Benchwork: SA, SZZ, SMA, AS, AA, SF

Analysis: SA

Original draft: SA, SZZ, SMA 
medRxiv preprint doi: https://doi.org/10.1101/2021.02.18.21252044; this version posted February 23, 2021. The copyright holder for this preprint (which was not certified by peer review) is the author/funder, who has granted medRxiv a license to display the preprint in perpetuity.

All rights reserved. No reuse allowed without permission.

Reviewing and editing: SA

Approval of final version: all authors 


\section{Table Legends}

Table 1. Participant information and clinico-pathological data of breast cancer patients

\begin{tabular}{|c|c|c|c|}
\hline Sr. No. & Characteristic & Value & p-value \\
\hline 1. & No. of participants (cases/controls) & $264(121 / 143)$ & N/A \\
\hline 2. & Mean Age [cases/controls: years_standard error of mean & $44.48 \pm 0.95 / 45.62+0.58$ & 0.306 \\
\hline \multirow{3}{*}{3.} & Tumour Stage $(n *=84)$ & & \\
\hline & I and II & I: $3(4 \%)$ and II: $30(36 \%)$ & \multirow[t]{2}{*}{$0.024 * *$} \\
\hline & III and IV & III: $46(55 \%)$ and IV: $5(5 \%)$ & \\
\hline \multirow{4}{*}{4.} & Tumour Size $(n *=102)$ & & \\
\hline & $<2 \mathrm{~cm}$ & $14(14)$ & \\
\hline & $2-5 \mathrm{~cm}$ & $58(57)$ & $<0.01^{* *}$ \\
\hline & $>5 \mathrm{~cm}$ & $30(29)$ & $>0.05$ \\
\hline \multirow{3}{*}{5.} & Tumour grade $(n *=107)$ & & \\
\hline & G1 and G2 & G1: $1(1 \%)$ and G2: $46(43)$ & \multirow[t]{2}{*}{$>0.05$} \\
\hline & G3 and G4 & G3: $58(54 \%)$ and G4: $2(2 \%)$ & \\
\hline \multirow{3}{*}{6.} & Treatment Response $(\mathrm{n} *=97)$ & & \\
\hline & Positive & $64(66 \%)$ & \multirow{2}{*}{$<0.01 * *$} \\
\hline & Negative (relapse and/or death) & $33(34 \%)$ & \\
\hline \multirow{3}{*}{7.} & 3-Year Survival $(n *=97)$ & & \\
\hline & Alive & $71(73 \%)$ & \multirow{2}{*}{$<0.01 * *$} \\
\hline & Expired & $26(27 \%)$ & \\
\hline
\end{tabular}

*available data from 121 patients (missing data has been explained in the methodology section); **statistically significant 
medRxiv preprint doi: https://doi.org/10.1101/2021.02.18.21252044; this version posted February 23, 2021. The copyright holder for this preprint (which was not certified by peer review) is the author/funder, who has granted medRxiv a license to display the preprint in perpetuity. All rights reserved. No reuse allowed without permission.

Table 2. Distribution of GSTT1 genotypes and allele frequencies (with standard errors) in age- and gender-matched controls. Assessment of HWE test in controls.

\begin{tabular}{|l|l|}
\hline GSTT1 Polymorphism & Controls (n = 143) \\
\hline Genotypes & \\
\hline GSTT1-present/ GSTT1-present & $66(46 \%)$ \\
\hline GSTT1-present/ GSTT1-absent & $61(43 \%)$ \\
\hline GSTT1-absent/ GSTT1-absent & $16(11 \%)$ \\
\hline Allele Frequencies & \\
\hline $\mathrm{p}[$ GSTT1-present] & \\
\hline $\mathrm{q}[$ GSTT1-absent] & $0.67 \pm 0.042$ \\
\hline & $0.33 \pm 0.042$ \\
\hline Hardy-Weinberg Equilibrium (HWE) Test & \\
\hline$\chi^{2}$ & 0.11 \\
\hline P-value & $\mathrm{NS}(0.74)$ \\
\hline
\end{tabular}


Table 3. Distribution of GSTT1 genotypes in controls, breast cancer patients, and the association analysis with breast cancer risk.

\begin{tabular}{|c|c|c|c|c|}
\hline GSTT1 Polymorphism & $\begin{array}{l}\text { Controls } \\
(\mathrm{n}=143)\end{array}$ & $\begin{array}{l}\text { Breast Cancer Patients } \\
\left(\mathrm{n}=118^{\natural}\right)\end{array}$ & $\begin{array}{l}\chi^{2} \text { Test }(p- \\
\text { value })\end{array}$ & OR $(95 \%$ CI $)$ \\
\hline GSTT1-absent/ GSTT1-absent & $16(11 \%)$ & $25(21 \%)$ & \multirow{2}{*}{$\begin{array}{l}\chi^{2}=4.88 \\
p=0.03 * *\end{array}$} & \multirow{2}{*}{$\begin{array}{l}2.13(1.08- \\
4.29)^{* *}\end{array}$} \\
\hline $\begin{array}{l}\text { GSTT1-present/ GSTT1-present \& } \\
\text { GSTT1-present/ GSTT1-absent }\end{array}$ & $127(89 \%)$ & $93(79 \%)$ & & \\
\hline
\end{tabular}

${ }^{9}$ Genotype could not be determined for three samples; **statistically significant

Table 4. Associations between GSTT1 genotypes and overall survival (OS)

\begin{tabular}{|l|l|l|l|l|l|}
\hline GSTT1 Polymorphism & \multirow{2}{*}{ No. (95) } & \multicolumn{3}{|c|}{ OS } \\
\cline { 3 - 6 } & & $\begin{array}{c}\text { Mean } \\
\text { (months) }\end{array}$ & $p$-value & \multicolumn{1}{|c|}{ HR } & 95\% CI \\
\hline GSTT1-absent/ GSTT1-absent & $21(22 \%)$ & 23 & $0.0001^{* *}$ & 8.13 & $2.91-22.96^{* *}$ \\
\hline $\begin{array}{l}\text { GSTT1-present/ GSTT1-present \& } \\
\text { GSTT1-present/ GSTT1-absent }\end{array}$ & $74(78 \%)$ & 33 & & Ref. & \\
\hline
\end{tabular}

**statistically significant 
medRxiv preprint doi: https://doi.org/10.1101/2021.02.18.21252044; this version posted February 23, 2021. The copyright holder for this preprint (which was not certified by peer review) is the author/funder, who has granted medRxiv a license to display the preprint in perpetuity.

All rights reserved. No reuse allowed without permission.

Table 5. Distribution of GSTT1-absent genotype in different regions across the globe

\begin{tabular}{|l|l|l|}
\hline Location (Population) & Frequency of GSTT1 Null Genotype & Reference \\
\hline Africa & & {$[48]$} \\
\hline Tunisia (central tunisian) & 0.29 & {$[49]$} \\
\hline Gambia (Wollof) & 0.5 & \\
\hline South America & & \\
\hline Mexico (Western Maxican) & 0.03 & {$[50]$} \\
\hline Paraguay (Ache) & 0.18 & {$[51]$} \\
\hline & & \\
\hline North America & & {$[52]$} \\
\hline USA (Whites) & 0.3 & {$[52]$} \\
\hline USA (African-Americans) & 0.33 & \\
\hline & & {$[53]$} \\
\hline Europe & & {$[54]$} \\
\hline Athens, Greece (Greek) & 0.1 & {$[58]$} \\
\hline Italy (Roman) & 0.33 & \\
\hline & & \\
\hline Asia & & {$[55,56]$} \\
\hline $\begin{array}{l}\text { Haifa, Israel (Druze), } \\
\text { Kabul Afghanistan } \\
\text { Pushtun) }\end{array}$ & 0.17 & \\
\hline & 0.53 & \\
\hline Seoul, Korea (Koreans) & & \\
\hline & & \\
\hline Oceania & & \\
\hline Australia & & \\
\hline
\end{tabular}




\section{$\underline{\text { Figure Captions }}$}

Fig. 1 The study schema. The prospective recruitment of cases with age-matched female controls is shown along with the collection of specified molecular, clinical, and survival data. The objective was to investigate contribution of GSTT1 variation in breast cancer risk, tumour characteristics and survival after standard treatment.

Fig 2. A representative $0.7 \%$ agarose gel used for quality control of extracted DNA samples. Lane 1: 100bp DNA ladder; lanes 2-12: DNA samples

Fig. 3 GSTT1 genotyping. Agarose gel electrophoresis (2\%) of multiplex PCR amplified products: GSTT1-absent (-ve/-ve) genotype did not show amplification of a $473 \mathrm{bp}$ fragment. $\beta$-globin gene was included as an amplification control.

Fig 4. Kaplan-Meier curve demonstrating the overall survival (OS) based on genotypes of GSTT1. The mean OS was 33 months (95\% CI: 30.96-34.65) in GSTT1-present genotype carriers and 23 months (95\% CI: 17.90-28.59) in GSTT1-absent genotype carriers; $p$-value: 0.0001.

Fig 5. Xeno- and endo-biotic carcinogen metabolism through two pathway system (phase I and phase II) is shown. Deletion of GSTT1 leads to toxicity and carcinogenesis (TCDD: 2,3,7,8-Tetrachlorodibenzodioxin; BaP: Benzo[a]pyrene; BPDE: Benzo(a)pyrene diolepoxide; ROS: Reactive Oxygen Species) 
Study Schema

Subject Enrollment $\downarrow$

Data Collection

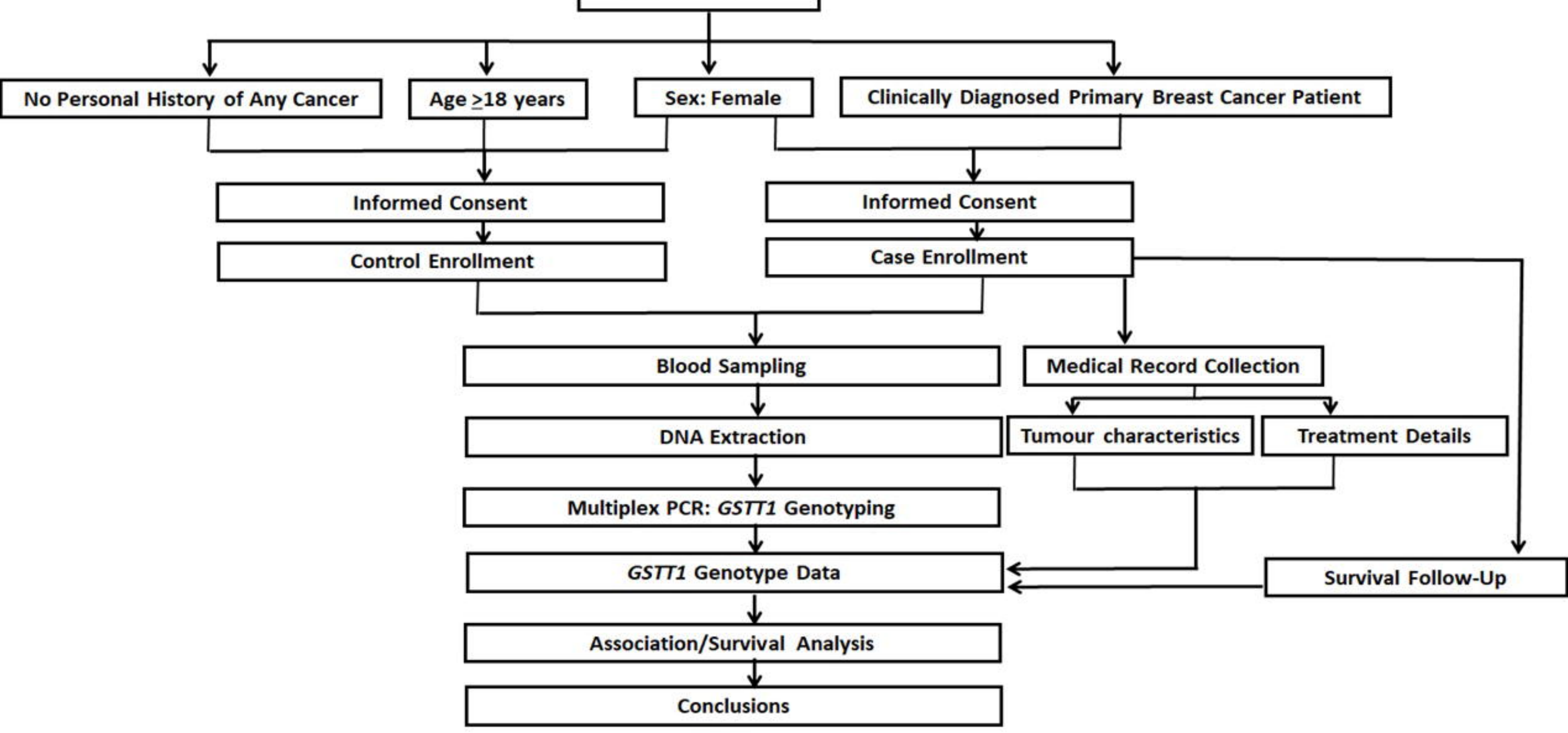


$\pi / m$

ve/ve loobp

$\perp$

tve

-ro-n

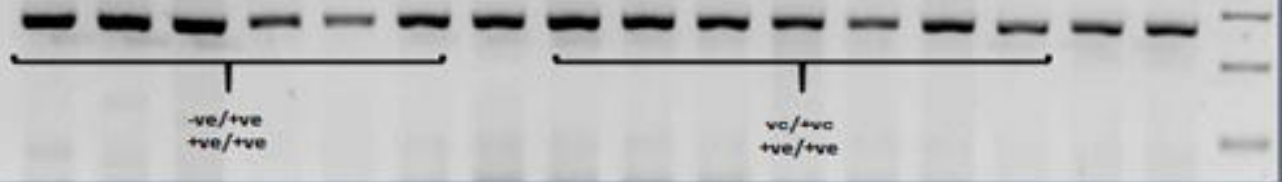

$1000 \mathrm{bp}$

$\leftarrow 473$ bp GSTT1

$\leftarrow 268$ bp 6-Globin 
OS

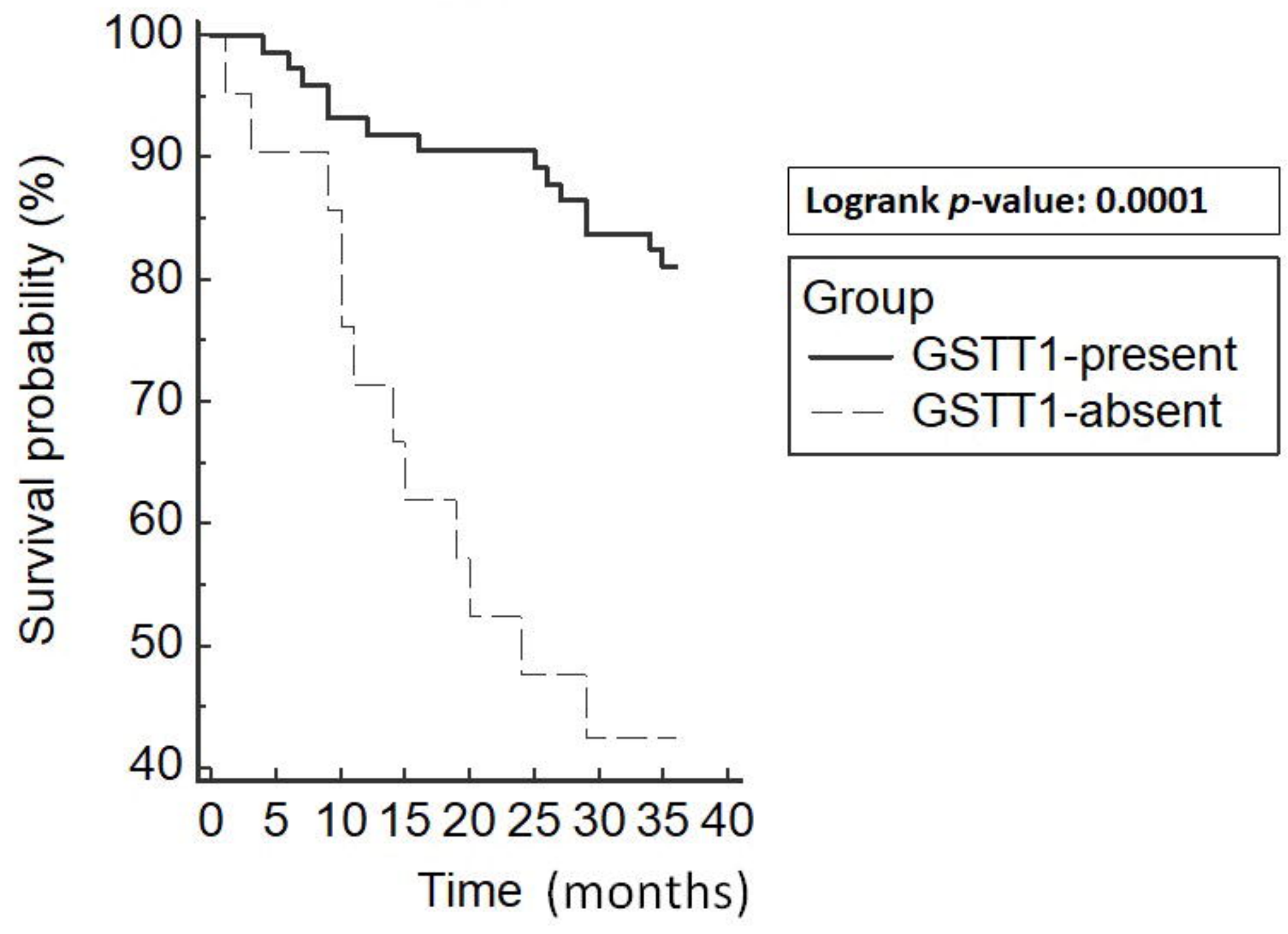


